\title{
A COMPARISON OF NATURAL GAS DEHYDRATION METHODS
}

\author{
Ebrahiem E. Ebrahiem, Ibrahim A. Ashour, M.M. Nassar, Abdel Aziz A. \\ Chemical Engineering Department, Faculty of Engineering, Minia University \\ E-mail:Ebrahiem59@yahoo.com
}

\begin{abstract}
The allowable moisture content of transmission natural gas ranges from 4 to 7 pounds per MMSCF $\left(64-112 \mathrm{mg} / \mathrm{m}^{3}\right)$. Water content may leads to solid hydrate formation, corrosion of pipelines \& process plants particularly in the presence of $\mathrm{CO}_{2}$ or $\mathrm{H}_{2} \mathrm{~S}$, slugging and erosion problems in the flowlines. Also, it leads to specific volume increasing, heating value decreasing and freezing in cryogenic and refrigerated absorption plants. Dehydration of natural gas is necessary in order to obtain a water dew point below operating temperature to avoid water condensation and subsequent free water on the system and hydrates formation. A comparison between different widely industry methods of natural gas dehydration is made in order to choose a method for achieving the required water dew point of export gas suitable for North Africa gas project. These methods are adsorption (using solid desiccants), absorption (using liquid desiccants), dehydration (by $\mathrm{CaCl}_{2}$, expansion refrigeration and membrane permeation). The comparison is made according to their energy demand and suitability for use in North African countries. At the central process facilities of North Africa project, flowline arrival pressure and temperature may be in the range 54 to $60 \mathrm{bar}$ and $25^{\circ} \mathrm{C}$ to $50^{\circ} \mathrm{C}$ (in winter to summer) respectively. In North Africa Gas Project at south Tunisia, the required water dew-point specification of export gas in field is $-12^{\circ} \mathrm{C}$ at any pressure. As a comparison result it was found that it is recommended to use a TEG (Triethylene Glycol) dehydration method due to many advantages.
\end{abstract}

Keywords: Natural Gas, Dehydration, Dehydration Methods, hydrate formation, absorption plane.

\section{INTRODUCTION}

A main sources of energy in human life is Natural gas. It becomes increasingly important alternative fossil fuel due to the depletion of crude oil. Before consumers use, natural gas must be processed or refined. Gas dehydration is one of the most important operations in gas processing to eliminate water vapor associated with natural gas [1]. The presence of water vapor in natural gas cause problems such as hydrate formation or freezing (which results pipe plugging), Corrosion (especially in the presence of $\mathrm{H}_{2} \mathrm{~S}$ and $\mathrm{CO}_{2}$ ) and reduction of combustion efficiency [2]. Netusil and Ditl. made a comparison between three methods for natural gas dehydration. These methods are absorption by triethylene glycol, adsorption on solid desiccants and condensation. He found that energy consumption under low pressure for the 
refrigeration method was the most demanding one and the absorption method was less demanding on the whole pressure scale [3]. The North Africa Gas Project field development consists of eight wells, a gathering system and a Central Processing Facility $(\mathrm{CPF})$ at which stream production from the various fields were separated into condensate and dew pointed gas products for export. The condensate will be exported via the existing Trans Saharan Pipeline Company (TRAPSA) oil pipeline to the La Skhira oil terminal near Gabes. The gas will be exported to a tie-in point at the LPG Project facilities from where it will be transported via a $320 \mathrm{~km}$ gas pipeline to Gabes and treated in a dedicated Liquefied Petroleum Gas (LPG) extraction facility to commercial specification required for end user consumption. The required water dew point in the export gas of North Africa Gas Project is $-12^{\circ} \mathrm{C}$ at any pressure. In the present work a comparison of all gas dehydration available methods applied in the industry to choose a suitable gas dehydration method for North Africa Gas Project gas development project in the south of Tunisia to achieve the export gas specifications. The comparison based on energy costs, market conditions (materials cost, consumables costs), technology evolution with time and company experience with a certain technology.

\section{DEHYDRATION METHODS}

\subsection{ABSORPTION DEHYDRATION USING GLYCOL}

Glycol possess the criteria for liquids suitable for absorbing water from gas in commercially viable processes. Due to its relatively high volatility, the use of monoethylene glycol (MEG) is limited to injection into a wet gas stream for hydrate suppression rather than water dewpoint depression by contact with gas in an absorber tower [4]. Other hand, diethylene glycol (DEG), triethylene glycol (TEG) and tetraethylene glycol (TREG) possess suitable properties for dewpoint depression i.e. dehydration through gas/liquid contact. However, the vast majority of the glycol dehydrators in service use TEG. DEG may be cheaper to buy in certain markets but when handling and other labour costs are accounted for there is little if any saving. Compared to TEG, DEG exhibits greater losses in carry-over, provides less dewpoint depression and regeneration to high concentrations is more difficult [5]. TREG is more viscous and more expensive than the other processes. It exhibits a lower vapor pressure which reduces absorber carry-over losses. It can be used in high temperature applications where dehydration of gases at temperatures in excess of $60^{\circ} \mathrm{C}$ is required. Additionally, TREG is not as readily available as TEG [6]. TEG is the most widely used and easily available desiccant for dehydration units. For the reasons outlined above the most suitable liquid desiccant for use at North Africa Gas Project is TEG. Property data for TEG and other glycols are shown in Table 1 and Figure 1 [7]. M.M. Ghiasi et al. studied the triethylene glycol (TEG) purity in natural gas dehydration units using fuzzy neural network, developed of an intelligent model based on the wellproven standard feed-forward backpropagation neural network for accurate prediction of TEG purity based on operating conditions of reboiler. He found that reducing the pressure in the reboiler at a constant temperature results in higher glycol purity [8]. M. A. Satyro and Schoegglb studied temperature change from isenthalpic expansion of aqueous triethylene glycol 
mixtures for natural gas dehydration. They found that for typical natural gas dehydration conditions, the depressurization of rich TEG solutions from $7000 \mathrm{kPa}$ to 440 $\mathrm{kPa}$ under isenthalpic conditions has a temperature increase in the order of $1.9 \mathrm{~K}$.
The isenthalpic expansion across the valve was modeled with a cubic equation of state and classic quadratic mixing rule with interaction parameters determined based only on VLE data. The model predicted a temperature increase in the order of $2.5 \mathrm{~K}$ for all mixtures studied in this work [9].

TABle 1: PhysiCAL Properties OF GLYCOLS

\begin{tabular}{|c|c|c|c|c|}
\hline & $\begin{array}{l}\text { Mono-ethylene } \\
\text { Glycol (MEG) }\end{array}$ & $\begin{array}{c}\text { Diethylene } \\
\text { Glycol (DEG) }\end{array}$ & $\begin{array}{l}\text { Tri-ethylene } \\
\text { Glycol (TEG) }\end{array}$ & $\begin{array}{l}\text { Tetra-ethylene } \\
\text { Glycol (TREG) }\end{array}$ \\
\hline Formula & $\mathrm{C}_{2} \mathrm{H}_{6} \mathrm{O}_{2}$ & $\mathrm{C}_{4} \mathrm{H}_{10} \mathrm{O}_{3}$ & $\mathrm{C}_{6} \mathrm{H}_{14} \mathrm{O}_{4}$ & $\mathrm{C}_{6} \mathrm{H}_{18} \mathrm{O}_{5}$ \\
\hline Molecular Weight & 62.1 & 106.1 & 150.2 & 194.2 \\
\hline Boiling Point at $760 \mathrm{mmHg}-{ }^{\circ} \mathrm{C}$ & 197.3 & 244.8 & 285.5 & 314.0 \\
\hline Vapor Pressure at $25^{\circ} \mathrm{C}-\mathrm{mmHg}$ & 0.12 & $<0.01$ & $<0.01$ & $<0.01$ \\
\hline Vapor Pressure at $50^{\circ} \mathrm{C}-\mathrm{mmHg}$ & 0.62 & 0.06 & $<0.01$ & $<0.01$ \\
\hline Density @ $25^{\circ} \mathrm{C} \mathrm{kg} / \mathrm{m} 3$ & 1110 & 1113 & 1119 & 1120 \\
\hline Density@60 ․ kg/m3 & 1085 & 1088 & 1092 & 1092 \\
\hline Freezing point $-{ }^{\circ} \mathrm{C}$ & -13 & -8 & -7 & -5.5 \\
\hline Pour Point $-{ }^{\circ} \mathrm{C}$ & - & -54 & -58 & -41 \\
\hline Viscosity@25ㄷ - cP & 16.5 & 28.2 & 37.3 & 44.6 \\
\hline Viscosity @60 ${ }^{\circ} \mathrm{C}-\mathrm{cP}$ & 4.68 & 6.99 & 8.77 & 10.2 \\
\hline Surface Tension $\left(25^{\circ} \mathrm{C}\right)$ dyne $/ \mathrm{cm}$ & 47 & 44 & 45 & 45 \\
\hline Refractive Index $\left(25^{\circ} \mathrm{C}\right)$ & 1.430 & 1.446 & 1.454 & 1.457 \\
\hline Specific Heat $\left(25^{\circ} \mathrm{C}\right) \mathrm{kJ} /(\mathrm{kg} . \mathrm{K})$ & 2.43 & 2.30 & 2.22 & 2.18 \\
\hline Flash Point $-{ }^{\circ} \mathrm{C}$ (PMCC) & 116 & 124 & 177 & 204 \\
\hline
\end{tabular}

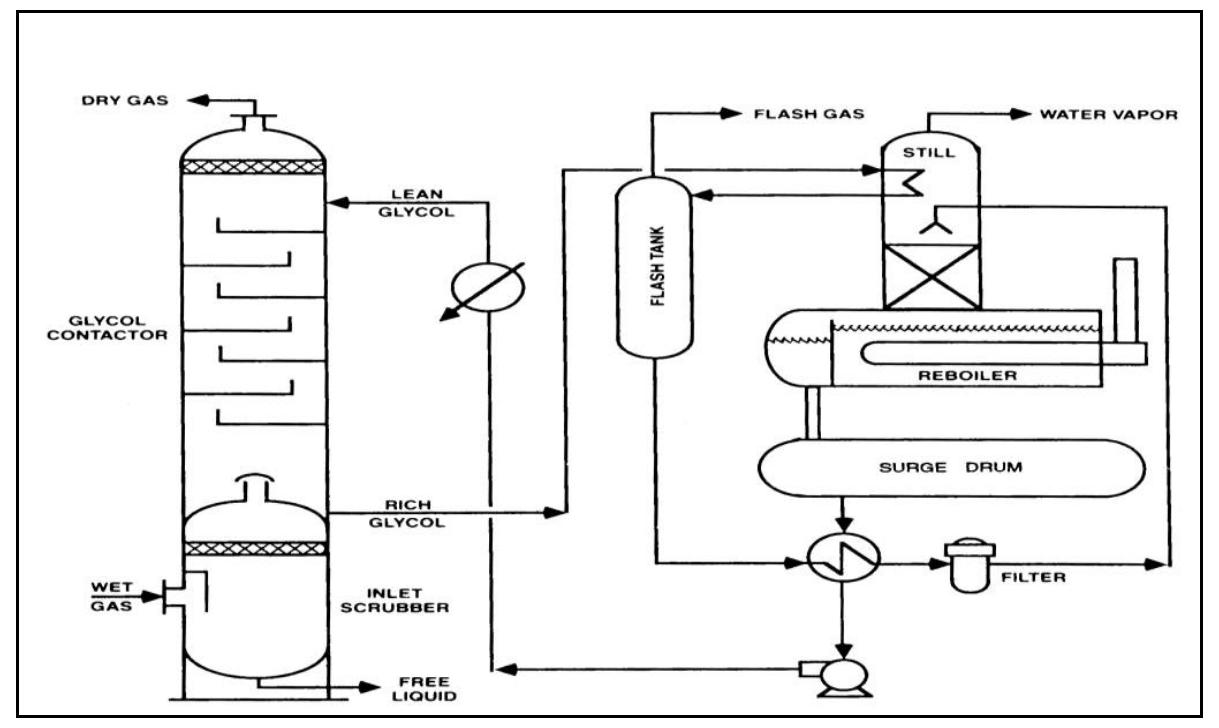

Fig. 1. Basic Flow scheme for Glycol Dehydration. 


\subsection{OTHER GLYCOL OPTIONS}

Other options to enhance glycol purity to achieve a high degree of water dewpoint depression include operation of the regenerator under vacuum, the proprietary Drizo process and the proprietary Coldfinger process.

\subsubsection{Stripping gas and Vacuum}

At boiling conditions of 1 atm and $204^{\circ} \mathrm{C}$ the maximum lean glycol mass concentration will be $98.6 \%$. If higher concentration, to meet the dewpoint specification is required, two different modifications can be introduced (the introduction of stripping gas to the regenerator or the regenerator operation at vacuum pressure) for lowering the partial pressure of the water in the vapor space of the glycol reboiler and enhance glycol concentration. The uses of stripping gas or the vacuum in the reboiler are the two most common methods for enhancement of the glycol concentration [10]. For stripping gas, any inert gas is suitable and gas can be introduced directly in the reboiler or on the packed unit between the reboiler and the surge tank. A less consume of gas is needed in case the second arrangement is utilized [11]. M.M. Ghiasi et al. studied Rigorous models to optimize stripping gas rate in natural gas dehydration units, found that based on the statistical analysis, an excellent match was noticed between the values obtained from the predictive tools and the real data. The average absolute relative deviation percent (AARD \%) was determined to be lower than $0.01 \%$ [12].

\subsubsection{DRIZO}

At this process, a solvent (in general, mixture of $70 \%$ aromatic, $20 \%$ naphthenic and $10 \%$ paraffin hydrocarbons) substitutes the stripping gas. This solvent vaporizes at reboiler temperature and is used as a stripping agent. Then, when it leaves the tower from its top, it is condensed and pumped back previously separation on a three phase vessel. The solvent and all BTEX compounds are condensed in this unit before the vapor is discharged to atmosphere $[13,14]$. Advantages: One of the more important advantages is that a high purity of TEG is performed (99.999 mass \%) with very high stripping flow rates and with little or no venting of hydrocarbons. Other advantage is that all BTEX compounds can be recovered from the vapor flow preventing from being sent to the atmosphere. DRIZO technology can be used to upgrade an existing unit in order to get higher glycol concentrations, or less BTEX and $\mathrm{CO}_{2}$ emissions. Disadvantages: A second particular solvent closed circuit is needed. This process has to be operated with some care to obtain a consistency constant operation. In addition, it has taken into account that in case utilizing this technology a license fee has to be paid.

\subsubsection{Coldfinger}

The Coldfinger process involves placing a cooling coil (Coldfinger condenser) in the vapor space above hot glycol in the surge drum, and a collecting tray is placed below the coil to catch condensate. The collected water/condensate from the Coldfinger condenser is collected in an accumulator from where it is periodically pumped back to the regenerator to recover the glycol and drive off the water [15]. The process requires a coolant to condense the water vapor and achieve a claimed $99.9 \%$ lean glycol concentration without the need for stripping gas. Also, a small amount of gas is required to be introduced to the surge drum to replace the volume of condensate drained 
from the Coldfinger to avoid drawing a vacuum; this gas leaves through the regenerator vent and effectively behaves like stripping gas although gas volumes may be less if carefully controlled [16]. Advantages: With these process a TEG purity of 99.96 mass $\%$ can be achieved without the use of stripping gas. Disadvantages: A cooling medium is needed and an additional set of pumps is required for the condensed waterTEG mixture.
M.R. Rahimpour et al. studied the performance of dehydration unit with Coldfinger technology in gas processing plant; found that Dehydrating by Coldfinger technology represents an effective method for removing water from natural gas [17]. A comparison between the different technologies is presented in Table 2 and Figure 2. The maximum TEG concentration and water dew point depression that can be achieved are presented in the table below.

TABle 2: TEG TECHNOLOGIES COMPARISON

\begin{tabular}{|c|c|c|}
\hline Method & [TEG] \% m/m (max.) & Water Dew Point depression [oC] \\
\hline Stripping & $99.2 / 99.98$ & $55 / 83$ \\
\hline Vacuum & $99.2 / 99.98$ & $55 / 83$ \\
\hline Drizo & $99.99+$ & $100 / 122$ \\
\hline Cold finger & 99.96 & $55 / 83$ \\
\hline
\end{tabular}

a) STRIPPING GAS
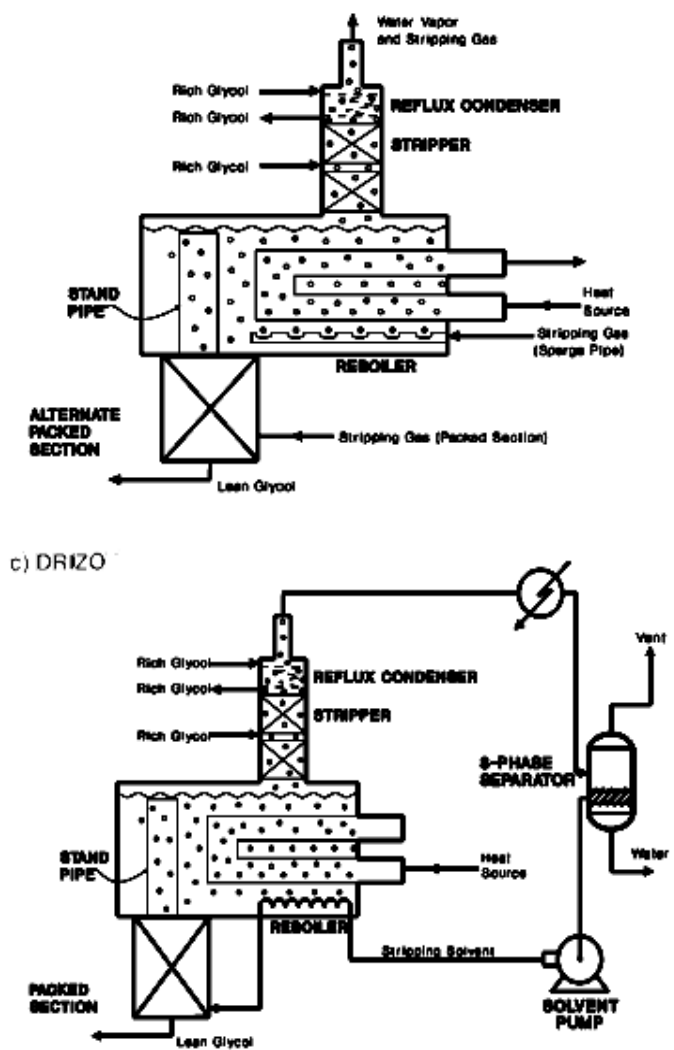

b) VACUUM

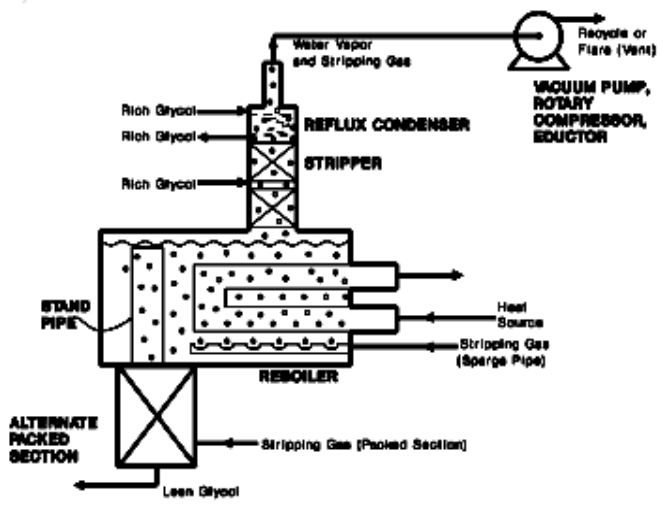

(1) COLDFINGER

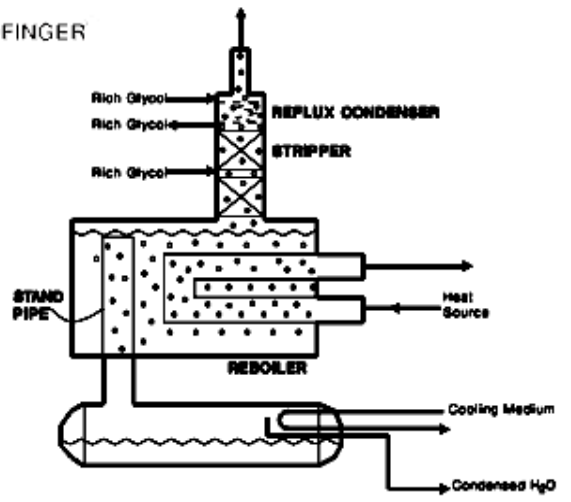

Fig. 2. Simplified flow diagram of Enhanced TEG regeneration system. 


\subsubsection{Adsorption Dehydration using solid desiccant}

There are several solid desiccants which possess physical characteristic to adsorb water from natural gas. Generally, in a simple two-tower system, the dehydration systems consisting of two or more towers and associated regeneration equipment in Figure 3. One tower is on stream adsorbing water from the gas while the other tower is being regenerated and cooled. Hot gas is used to drive off the adsorbed water from the desiccant, after which the tower is cooled with an unheated gas stream [18]. In general, the use of solids desiccant instead of liquids is associated to very low water dew point requirements, applications with high $\mathrm{H}_{2} \mathrm{~S}$ gases content, requirements of simultaneous control of hydrocarbon and water dew point. At cryogenic or very low temperature it is usually preferred the use of solid desiccants than inhibition, to avoid hydrate and/or ice formation [19]. The following three types of solids desiccants are usually used:

a. Silica Gel

Silica Gel basically, is a silicon dioxide, $\mathrm{SiO} 2$ and is used for gas and liquid dehydration. Also, it can be used for hydrocarbon recovery from natural gas. Dew point of approximately $-60^{\circ} \mathrm{C}$ can be achieved in hydrocarbon removal units that are commonly called HRUs (Hydrocarbon Recovery Units) or SCUs (Short Cycle Units) [20].

b. Alumina

Alumina (manufactured or natural) is a hydrated form of alumina oxide, $\mathrm{Al}_{2} \mathrm{O}_{3}$ which can be used for dehydration of liquid and gases and get water dew points of about $-70^{\circ} \mathrm{C}$ [21]. Advantages: In comparison with molecular sieves, alumina needs less regeneration heat because its regeneration temperature is lower. Disadvantages: Heavy hydrocarbons tend to get adsorbed in the alumina, making the alumina impossible to be regenerated. Alumina can also react with mineral acid.

c. Molecular Sieves

The molecular sieves are aluminosilicates (manufactured or naturals) having the highest selectivity and water capacity and consequently can get the lowest values of water dew point. These technology is commonly used upstream a NGL recovery plant, or in process where very cold temperatures are presents, to prevent hydrate and ice formation [22]. Water dew point of about $-100^{\circ} \mathrm{C}$ is possible to achieve with molecular sieves. With same changes on design or in operating parameters lower temperatures can be reached. To get a continuous process, a lead-lag arrangement is required, while one bed is operating, the other bed is getting regenerated and cooled. Cycles between 8 and 24 hours are usual. Molecular sieves are non-toxic, non-corrosive and available in different pore sizes [23,24]. Advantages: Main advantage is the lower water dew point than can be reached. Disadvantages: They are usually more expensive than the other alternatives. Table 3 below indicates the main advantages \& disadvantages of solid desiccants. H.A.A. Farag et al. studied the natural gas dehydration by desiccant materials, built up a pilot scale unit for natural gas dehydration as simulation of actual existing plant for Egyptian Western Desert Gas Company (WDGC). The effect of different operating conditions (water vapor concentration and gas flow rate) on dehydration of natural gas were studied. They found that increasing 
water vapor concentration in inlet feed gas leads to a marked decrease in dehydration efficiency, a higher inlet flow rate of natural gas decrease dehydration efficiency, increasing feed pressure leads to higher dehydration efficiency [25]. M. Takbiri et al. studied Preparation of nanostructured activated alumina and hybrid alumina-silica by chemical precipitation for natural gas dehydration, and found that the activated alumina was prepared from aluminum isobutanolate has maximum pore volume and humidity sorption capacity. Addition of hybrid to precursor was caused to exfoliate in structure of alumina and increasing of acidity and consequently the humidity sorption increased [26]. C. Zou et al. studied the Failure analysis and faults diagnosis of molecular sieve in natural gas dehydration, and found that there are four main aspects for the unavailability of the regenerative molecular sieve. First, the $\mathrm{pH}$ values and surface alkalinity decrease. Second, the secondary pore structure diminished and blocked. Third, the crystallite size increases, and the crystals agglomerated. Finally, not only the hydrocarbons adsorbed, but also alcohols, ethers and carbonyl sulfides generated in pores [27].

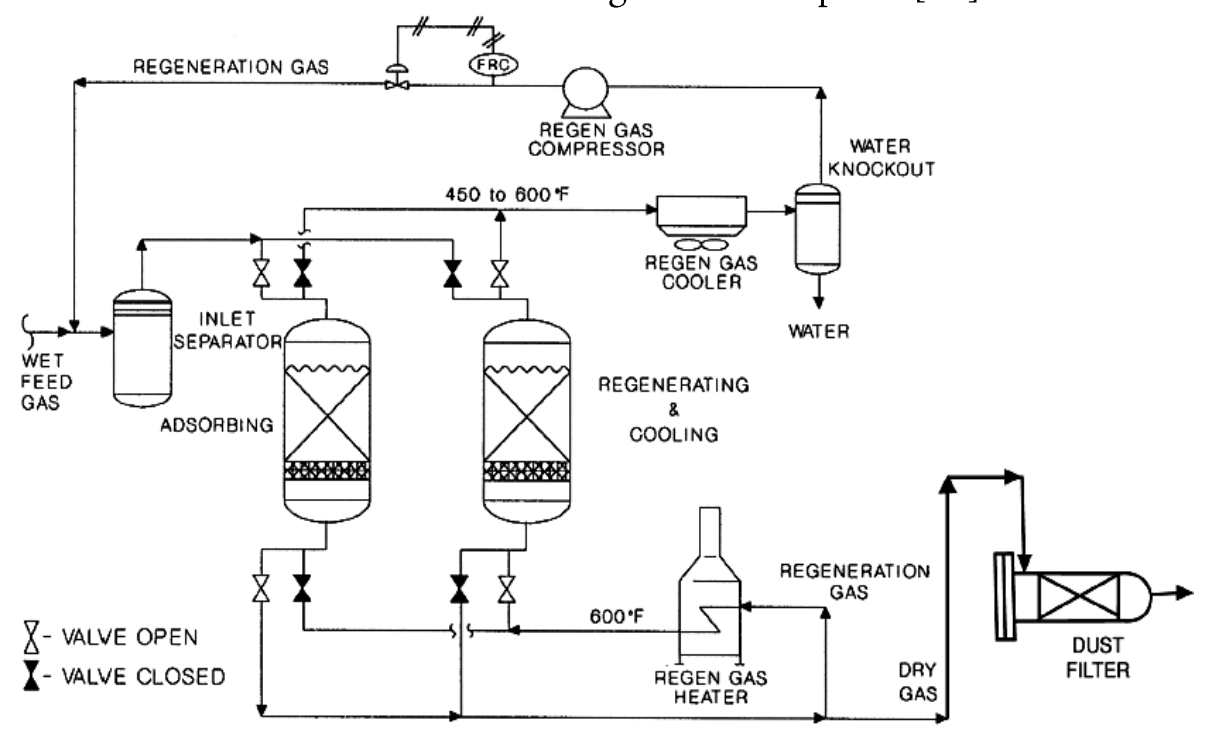

Fig.3 Basic Flow scheme for solid desiccants.

Table 3: Solid Desiccants (Adsorption Dehydration) Advantages / Disadvantages

\begin{tabular}{|l|l|}
\hline \multicolumn{1}{|c|}{ Advantages } & \multicolumn{1}{c|}{ Disadvantages } \\
\hline & $\begin{array}{l}\text { - Higher capital cost and higher pressure drops. } \\
\text { - Dew points as low as }-150^{\circ} \mathrm{F} .\end{array}$ \\
$\begin{array}{l}\text { - They are less affected by small changes in gas } \\
\text { Pressure, temperature and flow rate. }\end{array}$ & $\begin{array}{l}\text { - Mechanical breaking of desiccant particles. } \\
\text { - High regeneration heat requirements and high } \\
\text { utility costs. }\end{array}$ \\
\hline
\end{tabular}




\subsubsection{Dehydration by expansion refrigeration}

The dehydration of natural gas can also achieved by refrigeration and/or cryogenic processing down to $-100^{\circ} \mathrm{C}$ in the presence of methanol hydrate and freeze protection. The condensed water and methanol streams decanted in the cold process can be regenerated by conventional distillation or by a patented process called IFPEX-1[28]. In the latter process illustrated in schematic form in Figure 4, a slip stream of water saturated feed gas strips essentially all the methanol in the cold decanted methanol water stream originating in the cold process at feed gas conditions to recirculate the methanol to the cold process. The water stream leaving the stripper contains generally less than 100 ppm wt. of methanol. No heat is required for the process and no atmospheric venting takes place $[29,30]$.

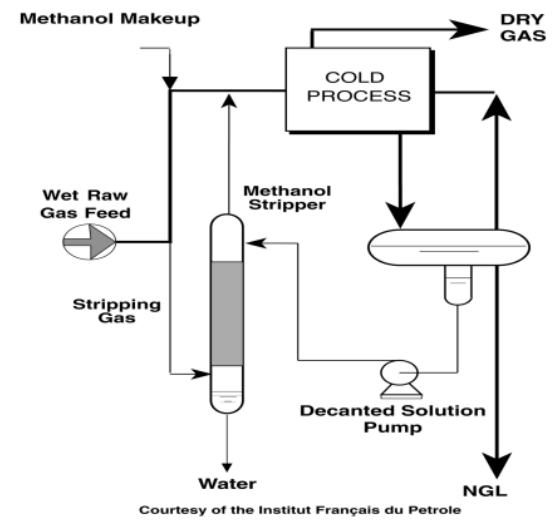

Fig. 4. Basic Flow scheme for dehydration by expansion refrigeration

\subsubsection{Dehydration by $\mathrm{CaCl} 2$}

The calcium chloride is a solid anhydrous that combinated with water generates a $\mathrm{CaCl}_{2}$ brine solution. Fixed beds of $\mathrm{CaCl}_{2}$ pellets are installed and the wetted gas flows through them [31]. Usually to increase unit capacity, 3 or 4 trays are installed below the solid bed to pre-contact the gas with the brine solution. In that way the upflows wetted gas get previously in contact with the brine solution and is a little dehydrated before taking contact with the dry solid desiccant[32]. Figure 5 below indicates the flow diagram of gas dehydration by $\mathrm{CaCl}_{2}$. Table 4 below indicates the advantages and disadvantages of gas dehydration by $\mathrm{CaCl} 2$.

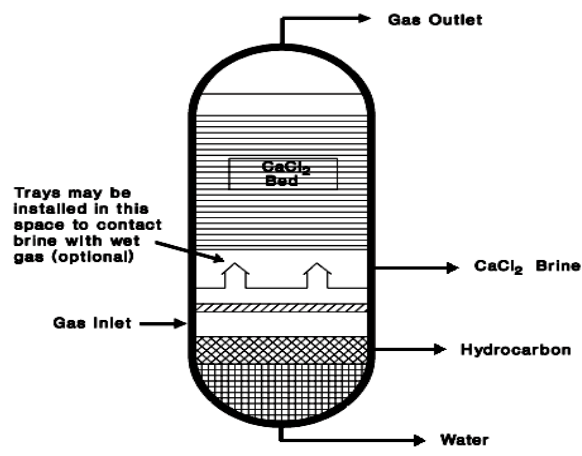

Fig. 5. Basic Flow scheme for dehydration by $\mathrm{CaCl}_{2}$

M.M. Ghiasi et al. studied Estimation of the water content of natural gas dried by solid calcium chloride dehydrator units, two mathematical-based models were developed to estimate approximate water content of natural gas dried by calcium chloride dehydrator, found that the results of both presented models were excellent agreement with reported data in the literature. The tools developed in this study can be of immense practical value for engineers to have a quick check on water content of natural gas dried by calcium chloride [33].

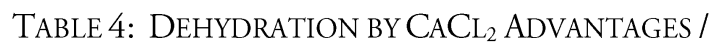
DISADVANTAGES

\begin{tabular}{|l|l|}
\hline \multicolumn{1}{|c|}{ Advantages } & \multicolumn{1}{|c|}{ Disadvantages } \\
\hline $\begin{array}{l}\mathrm{CaCl}_{2} \text { dehydrators can be } \\
\text { used on remote dry well gas } \\
\text { low rates. }\end{array}$ & $\begin{array}{l}\text { The calcium chloride is a } \\
\text { consumable desiccant to dehydrate } \\
\text { natural gas. It must be changed out } \\
\text { periodically. In low capacity - high } \\
\text { rate units this may be as often as } \\
\text { every 2-3 weeks. But the worst } \\
\text { disadvantages, and what have made } \\
\text { this technology less popular, are the } \\
\text { environmental problems of } \\
\text { disposing of the produced brine. } \\
\text { Additionally, unit performance } \\
\text { problems caused by gas channeling } \\
\text { in case pellets may became a solid } \\
\text { bridge" in the fixed bed. }\end{array}$ \\
\hline
\end{tabular}




\subsubsection{Dehydration by membrane permeation,}

Membranes can be used to separate gas stream components in natural gas such as water, $\mathrm{CO} 2$ and hydrocarbons according to their permeabilities. Each gas component entering the separator has a characteristic permeation rate that is a function of its ability to dissolve in and diffuse through the membrane [34]. The driving force for separation of a gas component in a mixture is the difference between its partial pressure across the membrane [35]. As pressurized feed gas flows into the metal shell of the separator, the fast gas component, such as water and $\mathrm{CO} 2$, permeate through the membrane [36]. This permeate is collected at a reduced pressure, while the nonpermeate stream, i.e., the dry natural gas, leaves the separator at a slightly lower pressure than the feed. The amount of methane and other natural gas components in the permeate stream is dependent on pressure drop and the surface area of the membranes. However, $5-10 \%$ of the feed stream is a realistic Figure 6. Dehydration by membrane permeation is therefore normally only considered for plants that can make use of low pressure natural gas fuel [37]. H. Lin et al. studied the dehydration of natural gas by using membrane technology, found that membrane processes with dry gas sweep on the permeate can be competitive with conventional glycol dehydrators for natural gas dehydration, and that spiral-wound modules with good sweep/countercurrent efficiency can be made [38]. McKee et al. compared diethanolamine PEA and membrane processes for a 1,000 psia gastreating plant. For their base case, the amine plant was found to be generally more economical for plant sizes greater than about 20 MMscfd [39]. S. Shirazian, S.N. Ashrafizadeh studied LTA and ion- exchanged LTA zeolite membranes for dehydration of natural gas, the effects of the molarity of $\mathrm{KCl}$ solutions and the repetition of ion-exchange on the membrane performance were investigated to produce high-quality KA membranes suitable for dehydration of natural gas. Found that the membrane ion-exchanged in $1 \mathrm{M} \mathrm{KCl}$ solution for two times had the best separation performance [40]. J. Zhao et al. studied Fabricating graphene oxide-based ultrathin hybrid membrane for pervaporation dehydration via layer-by-layer self-assembly driven by multiple interactions. They found that the optimized separation performance of hybrid multilayer membranes with the bilayer number 10.5 was obtained with the permeation flux of $2275 \mathrm{~g} / \mathrm{m}^{2} \mathrm{~h}$ and water content in permeate of 98.7 wt. \% under the conditions of $350 \mathrm{~K}$ and water content in feed of $20 \mathrm{wt} \%$ [41]. $X$. Chen et al. studied Fabrication of graphene oxide composite membranes and their application for pervaporation dehydration of butanol, found that graphene oxide membranes are suitable candidates for butanol dehydration via PV process [42]. J. Runhong Du et al. studied Membrane gas dehydration in a pressure-electric coupled field, the results also showed that the activation energy for water permeation was reduced by the electric field [43].

\section{DISCUSSION}

The North Africa Gas Project simulation indicates water content in the export gas of about $50 \mathrm{ppm}$ corresponding to a water dew point of $-15^{\circ} \mathrm{C}$ at $\mathrm{CPF}$ outlet pressure of 46.5 bar, which meets the export gas specification. This margin will provide operational flexibility and to cater for any upsets in glycol dehydration unit. A comparison is made between solid desiccants 
and liquid desiccants for North Africa Gas Project dehydration; Table 5 below indicates these comparisons.
Figure 6 represents a summarized selection chart for natural gas dehydration.

TABLE 5: COMPARISON OF LIQUID AND SOLID DESICCANTS

\begin{tabular}{|l|l|}
\hline \multicolumn{1}{|c|}{ Absorption using liquid desiccants } & \multicolumn{1}{c|}{ Adsorption using solid desiccants } \\
\hline Low installation cost & High installation costs \\
\hline Low pressure drop: $5-10 \mathrm{psi}$ & High pressure drop: $10-50 \mathrm{psi}$ \\
\hline Continuous process & Process in parallel \\
\hline Low ratio of heat regeneration / removed water & High ratio of heat regeneration / removed water \\
\hline Minimum water dew point $=-40^{\circ} \mathrm{C}$ & Minimum water dew point $=-100^{\circ} \mathrm{C}$ \\
\hline $\begin{array}{l}\text { For low water dew points other regeneration methods are } \\
\text { needed: Stripping, Drizo, etc. }\end{array}$ & $\begin{array}{l}\text { The reactive are poisoned in contact heavy } \\
\text { hydrocarbons. }\end{array}$ \\
\hline Low operating cost & High operating cost \\
\hline $\begin{array}{l}\text { Glycols are corrosive when are degradated or } \\
\text { contaminated }\end{array}$ & Less susceptible to corrosion or foaming. \\
\hline $\begin{array}{l}\text { Highly affected due to changes of flow, pressure and } \\
\text { temperature of the gas flow }\end{array}$ & $\begin{array}{l}\text { Not highly affected due to changes of flow, } \\
\text { pressure and temperature of the gas flow }\end{array}$ \\
\hline
\end{tabular}

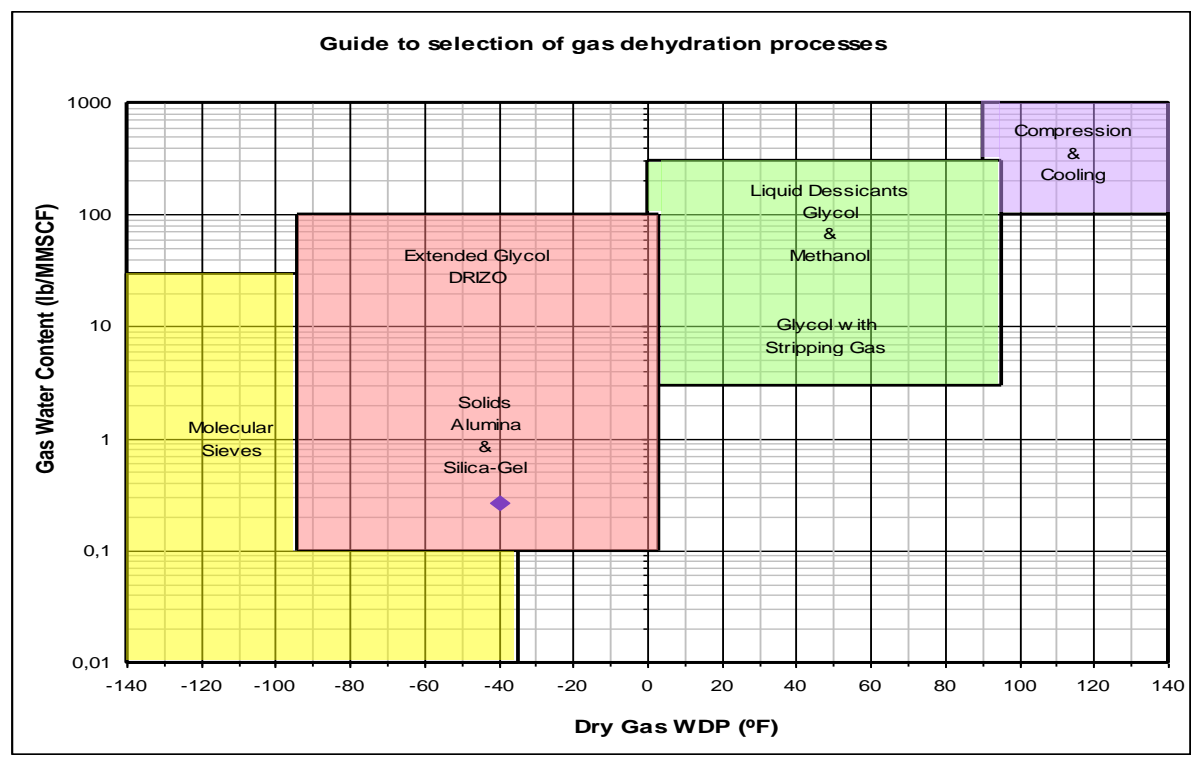

Fig.4. Gas dehydration technology selection chart.

From the above table, it can be noticed that Gas dehydration for North Africa Gas Project by using liquid desiccants is more suitable than using solid desiccants.
A comparison was made between Glycol and Molecular Sieve for gas dehydration. The Table 6 below indicates the main differences between Glycol and Molecular Sieve for gas dehydration. 
TABle 6: COMPARISON OF GLYCOL AND MOLECUlar SiEVE FOR GAS DEHYDRATION

\begin{tabular}{|l|l|}
\hline \multicolumn{1}{|c|}{ Glycol } & \multicolumn{1}{|c|}{ Molecular Sieve } \\
\hline $\begin{array}{l}\text { Glycol units have a single high pressure absorber } \\
\text { tower }\end{array}$ & $\begin{array}{l}\text { Molecular sieves require a minimum of two high pressure } \\
\text { adsorbers, sometimes more, depending on flow rates and } \\
\text { regeneration cycles }\end{array}$ \\
\hline Lower CAPEX & Higher CAPEX \\
\hline $\begin{array}{l}\text { Glycol units have lower peak utility consumption as } \\
\text { the glycol reboiler operates continuously }\end{array}$ & $\begin{array}{l}\text { Molecular sieve regeneration gas heater is a cyclic service; } \\
\text { therefore have higher peak utility consumption. }\end{array}$ \\
\hline $\begin{array}{l}\text { Glycol units operate at maximum temperature of } \\
204^{\circ} \text { C. The equipment that operates at high } \\
\text { temperature in a glycol unit is at low pressure. }\end{array}$ & $\begin{array}{l}\text { Molecular sieves operate at maximum temperature of }>315^{\circ} \mathrm{C} . \\
\text { The high temperatures occur at high pressures. }\end{array}$ \\
\hline $\begin{array}{l}\text { Lower pressures may result in a lower pressure piping } \\
\text { class for glycol unit equipment and piping e.g. class } \\
600 \text { RF. }\end{array}$ & $\begin{array}{l}\text { The combination of high temperature and high pressure may } \\
\text { dictate the use of a higher pressure piping class for the } \\
\text { molecular sieve equipment and piping e.g. class } 900 \mathrm{RTJ} . \text { This } \\
\text { may require an additional range of spare parts not found } \\
\text { elsewhere on the plant. }\end{array}$ \\
\hline Glycol units employ simple control loops only. & $\begin{array}{l}\text { Molecular sieves require relatively complex valve switching } \\
\text { logic and critical sequence timing. }\end{array}$ \\
\hline Gas pressure drop $<0.3$ bar & Gas pressure drop = 1.0 - 1.5 bar. \\
\hline Liquid phase water droplets do not affect glycol units. & $\begin{array}{l}\text { Molecular sieve desiccant material is intolerant to liquid phase } \\
\text { water droplets. Impact of droplets on the sieve causes severe } \\
\text { degradation of the desiccant producing fine solid particles, } \\
\text { which migrate through the bed and entrained in the gas. } \\
\text { Additional filters require maintenance and carry an attendant } \\
\text { risk of non-performance. }\end{array}$ \\
\hline No fine particles present in Glycol unit. & $\begin{array}{l}\text { Attrition of desiccant creates fine particles of molecular sieve } \\
\text { material, which entrained, in the dry gas. A fine gas filter is } \\
\text { required downstream adding to the overall pressure drop of } \\
\text { the system. }\end{array}$ \\
\hline
\end{tabular}

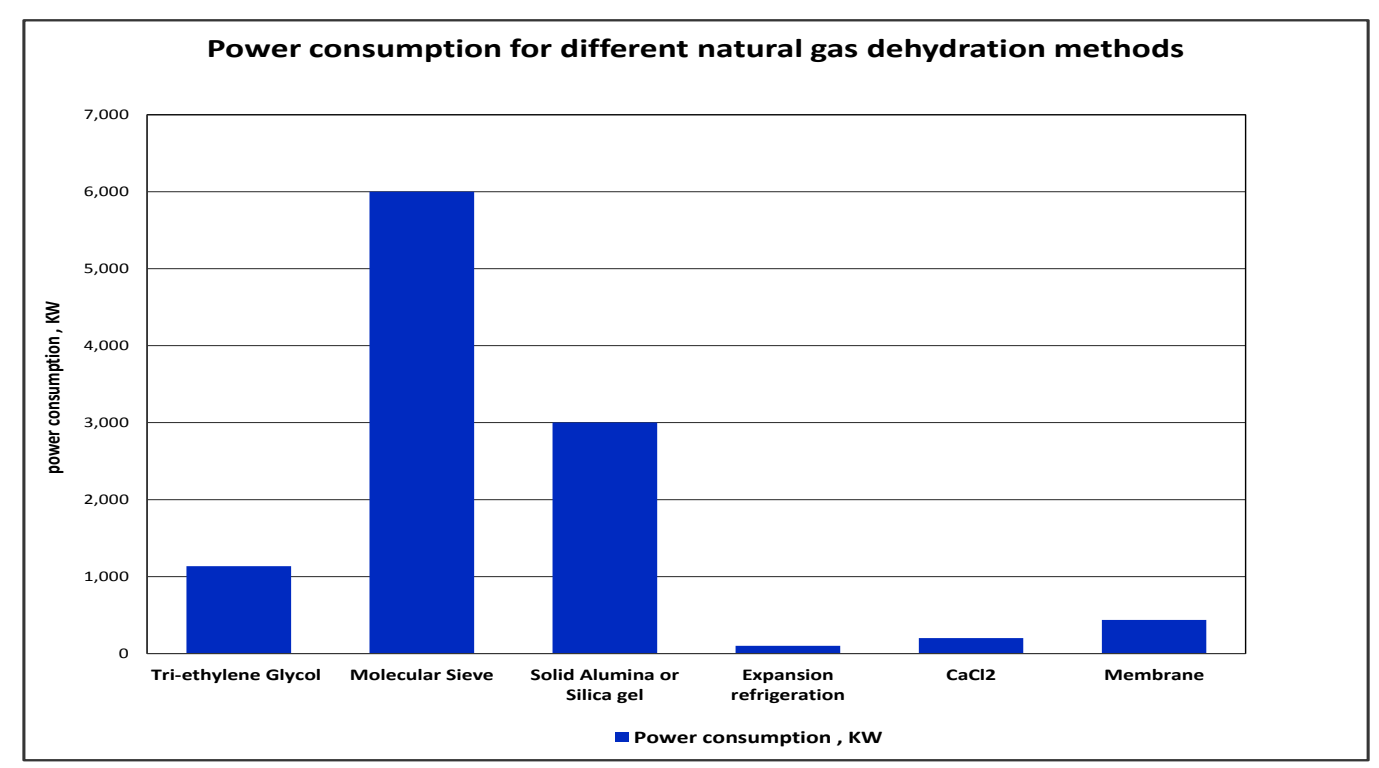

Fig. 7. Power consumption for different natural gas dehydration methods. 
Figure 7 indicates the power consumption for each dehydration method for the North Africa project.
Figure 8 indicates the capital cost in million USD for each dehydration method for the North Africa project.

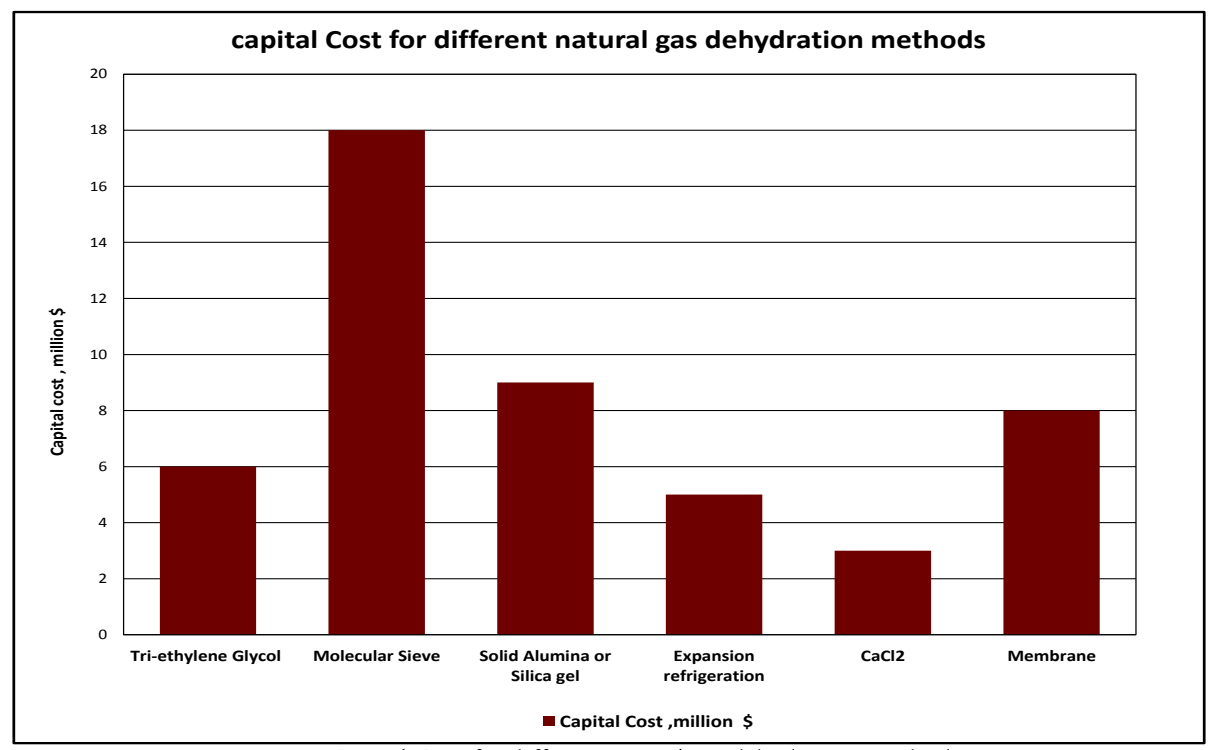

Fig. 8. Capital Cost for different natural gas dehydration methods.

TABLE 7: COMPARISON BETWEEN DEHYDRATION METHODS

\begin{tabular}{|c|c|c|c|c|c|c|}
\hline Technology & $\begin{array}{c}\text { Tri- } \\
\text { ethylene } \\
\text { Glycol }\end{array}$ & $\begin{array}{l}\text { Molecular } \\
\text { Sieve }\end{array}$ & $\begin{array}{c}\text { Solid } \\
\text { Alumina or } \\
\text { Silica gel }\end{array}$ & $\begin{array}{l}\text { Expansion or } \\
\text { refrigeration }\end{array}$ & $\mathrm{CaCl}_{2}$ & Membrane \\
\hline $\begin{array}{l}\text { Power } \\
\text { Consumption, } \\
\text { KW }\end{array}$ & 1,135 & 6,000 & 3,000 & 100 & 200 & 437 \\
\hline Suitability & Yes & Yes & No & No & No & No \\
\hline Limition & None & $\begin{array}{l}\text { Feed } \\
\text { temperature, } \\
\text { Product Loss }\end{array}$ & None & None & $\begin{array}{l}\text { 1- Environmental } \\
\text { problems } \\
\text { 2- Performance } \\
\text { problems }\end{array}$ & $\begin{array}{l}\text { Fragility, } \\
\text { Short Life, } \\
\text { Product loss }\end{array}$ \\
\hline $\begin{array}{l}\text { North Africa } \\
\text { Reference }\end{array}$ & Yes & Yes & NA & NA & NA & NA \\
\hline $\begin{array}{ll}\text { Capital } & \text { Cost, } \\
\text { million } \$ & \\
\end{array}$ & 6 & 18 & 9 & 5 & 3 & 8 \\
\hline
\end{tabular}

Table 7, above summarizes the main differences between the dehydration methods. From the above table and chart, it can be noticed that removal of $\mathrm{H}_{2} \mathrm{O}$ from gas project in North Africa by using triethylene Glycol is the best choice to achieve the export gas specifications.

\section{CONCLUSION AND RECOMMENDATION}

It is recommended to use a TEG (Triethylene Glycol) based dehydration unit to meet the FEED filters such as robustness (operational flexibility), simplicity, and use of proven technology (increased operator awareness with no additional training, 
operating experience etc.). It also recommended to cool the gas to $30^{\circ} \mathrm{C}$ to optimize the dehydration unit by reducing the size of the Glycol Contactor and Glycol Regeneration Unit. This also relaxes the glycol purity requirements to approximately 99\%wt., which minimizes and may eliminate stripping gas requirements; however provision for stripping gas will be retained in the design to allow flexibility to handle plant upsets and to debottleneck the TEG regeneration system in future.

\section{NOMENCLATURE}

\begin{tabular}{|c|c|}
\hline Abbreviation & Description \\
\hline BS\&W & Basic sediment and water \\
\hline BTEX & $\begin{array}{c}\text { Benzene, Toluene, Ethyl benzene } \\
\text { and Xylene }\end{array}$ \\
\hline CAPEX & Capital Expenditure \\
\hline CPF & Central Processing Facility \\
\hline DEG & Diethylene glycol \\
\hline DGA & Diglycol amine \\
\hline FEED & Front End Engineering and Design \\
\hline HSE & Health, Safety and the Environment \\
\hline LPG & Liquefied Petroleum Gas \\
\hline MEG & Monoethylene glycol \\
\hline OPEX & Operating Expenditure \\
\hline PPm & Part per million \\
\hline TEG & Triethylene glycol \\
\hline TREG & Tetraethylene glycol \\
\hline
\end{tabular}

\section{REFERENCES}

[1] Campbell, J.M., Gas Conditioning and processing, seventh ed. In: Campbell Petroleum Series Oklahoma, 1992.

[2] GPSA, 12th ed., Gas Processors Suppliers Association, USA, 2004.

[3] Michal Netusil, Pavel Ditl., Comparison of three methods for natural gas dehydration, Journal of Natural Gas Chemistry Vol. 20 No. 5, 2011.
[4] Vincente, N., Hernandez-Valencia Michael, W.H., Jerry, A.B., Design glycol dehydration units for maximum efficiency. In: Proceedings of the Seventy First GPA Annual Convection, Tulsa, Oklahoma-Oklahoma, pp. 310317,1992.

[5] Gandhidasan P. Parametric analysis of natural gas dehydration by a triethylene glycol solution. Energy Sources; 25:189-201, 2003.

[6] Hernandez-Valencia, V.N, Hlavinka, M.W., Bullin, J.A., "Design Glycol Units for Maximum Efficiency," Proc. $71^{\text {st }}$ Ann. Convention of Gas Processors Association, p310, Tulsa 1992.

[7] D. Charles, C. Holland, F. Rayford, G. Anthony, Fundamentals of Chemical Reaction engineering, Prentice-Hall International Inc., 2003.

[8] M.M. Ghiasi , A. Bahadori, S. Zendehboudi, Estimation of triethylene glycol (TEG) purity in natural gas dehydration units using fuzzy neural network, Journal of Natural Gas Science and Engineering 17, 26-32, 2014.

[9] M. A. Satyro, F. Schoegglb, Temperature change from isenthalpic expansion of aqueous triethylene glycol mixtures for natural gas dehydration H.W. Yarrantonb, Fluid Phase Equilibria 305, 62-67, 2011.

[10] Gandhidasan P. Parametric analysis of natural gas dehydration by a triethylene glycol solution. Energy Sources; 25:189-201, 2003.

[11] Løkken, T.V., Bersås, A., Christensen, K.O., Nygaard, C.F., Solbraa, E., 2008. Water content of high pressure natural gas: data, prediction and experience from field. In: International Gas Research Conference Proceedings, vol. 3, pp. 1979, 2011.

[12] M.M. Ghiasi, A. Bahadori, S. Zendehboudi, I. Chatzis, Rigorous models to optimize stripping gas rate in natural gas dehydration units, Fuel 140, 421-428, 2015.

[13] Carlson JW, Rhinesmith RB. Low pressure dehydration unit process selection and operating successes for coal bed natural gas. In: Proceedings, annual convention - gas processors association, USA; pp. 828-47, 2007.

[14] Stewart M, Arnold K. Gas dehydration field manual. MA (USA): Gulf Professional Publishing ; 201 
[15] M.R. Rahimpour , S.M. Jokar , P. Feyzi , R. Asghari , Journal of Natural Gas Science and Engineering 12. 1-12, 2013.

[16] Pearce, R. L.; Sivalls, C. R. Fundamentals of gas dehydration, design and operation with glycol solutions. In Gas Conditioning Conference; University of Oklahoma: Norman, OK, 1984.

[17] M.R. Rahimpour , S. M. Jokar, P. Feyzi, R. Asghari, Investigating the performance of dehydration unit with Coldfinger technology in gas processing plant, Journal of Natural Gas Science and Engineering 12, 1-12, 2013

[18] P. Gandhidasan, A. Abdulgarak, A. AlFarayedhi, A. Al- Mubarak, Dehydration of Natural Gas Using Solid Desiccants, Pergamon, 2001.

[19] Lyons, W.C., Plisga, G.J Standard Handbook of Petroleum and Natural Gas Engineering, second ed. Gulf professional, Imprint of Elsevier, Burlington, MA, USA, 2005.

[20] W. Vyalkina, Gv. Nabutovskii, Z.A. Popov, V.I. Turevskii, Silica gel application, Chemistry and Technology of Fuel and Oil 21 (5-8), 1990.

[21] J. Maria, R. Rivero, M. Ibanez, O. Inmaculada, Mathematical modelling of styrene drying by adsorption on to activated alumina, Chemical Engineering Science 57. 2002.

[22] S. Ranjani, S. Ming, F. Edward, P. James, H. Duane, Adsorption of $\mathrm{CO} 2$ on Molecular Sieves and Activated Carbon, National Energy Technology Laboratory, USA, 2005.

[23] D. Charles, C. Holland, F. Rayford, G. Anthony, Fundamentals of Chemical Reaction Engineering, Prentice-Hall International Inc., 2003.

[24] B. Ceydi, Aysegul Askin, Evaluation of thermodynamic parameter for the adsorption of some hydrocarbons on alumina and molecular sieves 3A\& 5A by inverse gas chromatography, Journal of Chromatography, 2003.

[25] H.A.A. Farag, M.M Ezzat, H. Amer, A.W. Nashed, Natural gas dehydration by desiccant materials , Alexandria Engineering Journal, 50, 431-439, 2011.

[26] M. Takbiri, K.J. Jozani, A.M. Rashidi, H.R. Bozorgzadeh, Preparation of nanostructured activated alumina and hybrid alumina-silica by chemical precipitation for natural gas dehydration, Microporous and Mesoporous Materials, 182, 117-121, 2013.
[27] C. Zou, P. Zhao, M.W., D. Liu, H. Wang, Z. Wenc, Failure analysis and faults diagnosis of molecular sieve in natural gas dehydration, Engineering Failure Analysis 34 (2013) 115120.

[28] Kohl, L., Nielsen, R.B. Gas Purification, fifth ed. Gulf Publishing Company, Houston, 1997.

[29] Minkkinen, A., Larue, J. and Patel, S., "Methanol Gas Treating Scheme Offers Economics, Versatility," The Oil and Gas Journal, June 1, p. 65, 1992.

[30] Mokhatab, S., Poe, W.A., Handbook of Natural Gas Transmission and Pro- cessing. Gulf Professional Publishing, 2006.

[31] Dow Chemical Company Report, Gas Dehydration with PELADOW DG Calcium Chloride. USA; May 1998.

[32] Bahadori A, Vuthaluru HB. Simple methodology for sizing of absorbers for TEG (triethylene glycol) gas dehydration systems. Energy; 34(11):1910-6, 2009.

[33] M.M. Ghiasi, A. Bahadori, S. Zendehboudi, Estimation of the water content of natural gas dried by solid calcium chloride dehydrator units, Fuel 117, 33-42, 2014

[34] R.W. Baker, K. Lokhandwala, Natural gas processing with membranes: an overview, Ind. Eng. Chem. Res. 47, 2109-2121, 2008.

[35] R.W. Baker, Membrane Technology and Applications, 2nd ed., Wiley and Sons, Ltd., Chichester, UK, 2004.

[36] J.F. Davis, Gas Processors' National Association Meeting, Tulsa, OK, 1995.

[37] K. Lokhandwala, I. Pinnau, Z. He, K. Amo, J.C.D. Da Costa, H. Wijmans, R. Baker, Membrane separation of nitrogen from natural gas: a case study from membrane synthesis to commercial deployment, J. Membr. Sci. 346, 270-279, 2010.

[38] H. Lin , Scott M. Thompson, Adrian Serbanescu-Martin, Johannes G. Wijmans,Karl D. Amo, Kaaeid A. Lokhandwala, Timothy C. Merkel, Journal of Membrane Science 432, 106-114, 2013

[39] McKee, R. L., Changela, M. K., and Reading, G. L., Hydro. Process, Vol. 70, No. 4, April, p. 63, 1991.

[40] S. Shirazian, S.N. Ashrafizadeh, Synthesis of substrate-modified LTA zeolite membranes for 
dehydration of natural gas, Journal of Industrial and Engineering Chemistry 22,132-137, 2015.

[41] J. Zhao, Y. Zhu, F. Pan, G. He, C. Fang, K. Cao, R. Xing, Z. Jiang, Fabricating graphene oxide-based ultrathin hybrid membrane for pervaporation dehydration via layer-by-layer self-assembly driven by multiple interactions Journal of Membrane Science 487, 162-172, 2015.
[42] X. Chen, G. Liu, H. Zhang, Y. Fan, Fabrication of graphene oxide composite membranes and their application for pervaporation dehydration of butanol, Chinese Journal of Chemical Engineering 23, 1102-1109, 2015.

[43] J. Runhong Du, X. Shi, X. Feng, Y. Li, Y. Zhang, X., Membrane gas dehydration in a pressure-electric coupled field ,Journal of Membrane Science 493, 444-451, 2015. 


\author{
مقارنة بين طرق إزالة الرطوبة من الغاز الطبيعي \\ إبر اهيم إبر اهيم، إبر اهيم أ. عاثور، م. م. نصار، عبد العزيز أ. \\ قسم الهنسة الكيميائية، كلية الهندة، جامعة المنيا.
}

الملخص:

يتر اوح محتوى الرطوبة المسموح به في الغاز الطبيعي من 4 إلى 7 رطل لكل مليون قدم مكعب قياسي, (64112 ملغ / م³). وجود الرطوبة قد يؤدي إلى تثكيل هيدرات صلبة، نآكل خطوط الأنابيب ومحطات المعالجة وخاصة في وجود CO أو CO H و مشاكل الركود و التآكل في خطوط التدفق. كما أنه يؤدي إلى زيادة معينة في الحجم، وانخفاض في مقدارالتسخين بالاضافة الى تجمد في محطات امتصاص المبردة والمجدة. جفاف الغاز الطبيعي ضروري من أجل الحصول على نقطة الندى للماء تحت درجة حر ارة التشغيل لتجنب تكثف المياه و المياه الحرة اللاحقة على النظام وتثكل الهيدرات. تم عمل مقارنة بين طرق الصناعية المختلفة على نطاق و واسع والمستخدمة في تجفيف الغاز الطبيعي من أجل اختيار طريقة تحقق نقطة الندى للماء المطلوبة في غاز التصدير ومناسبة لمشروع غاز شمال أفريقيا. هذه الطرق هي الامتزاز (باستخدام المجففات الصلبة)، و الامتصاص (باستخدام المجفات السائلة)، و التجفيف (بو اسطة CaCl2 ل، التبريد التوسعي و التغلغل الغشائي). تم عمل المقارنة وفقا لمنطلبات الطاقة وملائمتها للاستخدام في بلدان شمال أفريقيا. في مر افق العمليات المركزية في شمال أفريقيا، يمكن أن يكون الضغط ودرجات الحرارة الحاصلة عند وصول التدفق من 54 إلى 60 بار و 25 درجة مئوية إلى 50 درجة مئوية (في الثتاء إلى الصيف) على التو الي، في مشروع شمال أفريقيا للغاز في جنوب نونس، فإن مواصفات نقطة الندى المطلوبة من غاز التصدير في الحقل هي -12 درجة مئوية عند أي ضغط. ونتيجة للمقارنة وجد أنه من المستحسن استخدام ثلاثي إيثيلين جلايكول كطريقة للتجفيف بسبب العديد من 